\title{
Surfactant free metal chalcogenides microparticles consisting of nano size crystallites: room temperature synthesis driven by the supersaturated condition
}

\author{
SANYASINAIDU GOTTAPU, VENKATESWARA RAO VELPURI and \\ KRISHNAMURTHI MURALIDHARAN* (D) \\ School of Chemistry, University of Hyderabad, Prof. C. R. Road, Gachibowli, Hyderabad, Telangana 500046 , \\ India \\ E-mail: murali@uohyd.ac.in
}

MS received 26 July 2017; revised 15 September 2017; accepted 25 September 2017; published online 11 November 2017

\begin{abstract}
A versatile methodology for the production of organic surfactant-free metal chalcogenide microparticles consisting of nano crystallites at room temperature in a short time is described. The reaction of various metal sources with $\mathrm{LiBH}_{4}$ in the presence of either $\mathrm{S}$ or Se yielded their corresponding $\mathrm{CuS}, \mathrm{Cu}_{2} \mathrm{~S}$, $\mathrm{CdS}$ and $\mathrm{Cu}_{2-z} \mathrm{Se}$ microparticles. These micron size particles are aggregates of nano crystallites. The reactivity of $\mathrm{LiBH}_{4}$ and supersaturated condition helped in the formation nanocrystals. The first observation of metal source dependent morphology of particles produced under identical reaction condition is also discussed. The morphology of $\mathrm{CuS}$ particles obtained in these reactions was varying with the change of metal source used in the reaction. Interestingly, the reactions producing metal chalcogenide microparticles also yielded borane $\left(\mathrm{BH}_{3}\right)$ as a side product.
\end{abstract}

Keywords. Metal chalcogenides; copper sulphide; copper selenide; micro flowers.

\section{Introduction}

The synthesis of metal chalcogenide ( $\mathrm{S}, \mathrm{Se}, \mathrm{Te})$ nano/ micro size particles is fascinating since they possess properties that depend on the composition of material, size and shape of the particles. ${ }^{1}$ The unique optical properties of these metal chalcogenides made them useful for multiple potential applications in biological, ${ }^{2,3}$ light emitting and photovoltaic devices. ${ }^{4-8}$ Among the metal sulphides, copper sulphide ( $\mathrm{CuS})$ is a less hazardous material, and relatively cheap. It is an important p-type semiconductor and exhibits many unusual electronic, optical, and other physical and chemical properties. It has great potential in a versatile range of applications such as optical filters, superionic materials, solar radiation absorbers, catalysts, nanometer-scale switches, high-capacity cathode material in lithium secondary batteries, superconductors, chemical sensors and thermoelectric cooling material. ${ }^{7-11}$ Therefore, copper sulphide is a valuable material for the construction of devices for various applications.

Copper sulphide has attracted significant interests because of the variations in stoichiometric compositions, valence states, nanocrystal morphologies and differences in the crystal structures. ${ }^{12}$ The variation in stoichiometric compositions of copper sulphide resulted in five polymorphic forms, viz. chalcocite $\left(\mathrm{Cu}_{2} \mathrm{~S}\right)$, djurleite $\left(\mathrm{C}_{1.95} \mathrm{~S}\right)$, digenite $\left(\mathrm{Cu}_{1.8} \mathrm{~S}\right)$, anilite $\left(\mathrm{Cu}_{1.7} \mathrm{~S}\right)$ and covellite $(\mathrm{CuS}) .{ }^{12}$ Copper sulphide was synthesized using the following methods; viz., thrombolysis, template assisted growth, microwave irradiation, hydrothermal or solvothermal, sonochemical techniques, CVD, soft template way and electrochemical method. ${ }^{13-19}$ However, those methods are expensive and complicated because of the presence of surfactants and templates that introduce impurities to the products. Further, a selective synthesis of one of the polymorphs is a challenge.

\footnotetext{
*For correspondence

Electronic supplementary material: The online version of this article (https://doi.org/10.1007/s12039-017-1381-4) contains supplementary material, which is available to authorized users.
} 
The collective properties of nanomaterials are not utilized fully ${ }^{12}$ because of the presence of organic surfactant molecules around the nano/micro particles that synthesized via regular chemical synthetic methods. Further, the capping agents or surfactants molecules around the particles may contribute negatively to the targeted applications. A few important points needing attention are ${ }^{20}$ (i) Capping agents isolate the neighbouring particle and decrease the communication between them. (ii) Shielding nature of capping agents hinders the charge carriers and thus affects the electronic devices made out of them. (iii) When the metal nano/micro particles are used as a catalyst, the chemical reaction occurs on the surface of the particles. The presence of capping would hide the active centres and restricts or reduce the catalytic activity. (iv) The surfactant molecules around nano/micro particles used for biological applications can be toxic for the human. All these observations suggest that it is crucial to design a method to produce applied nanomaterials without organic molecules surrounding.

Understanding the mechanism of formation of nanoparticles would help to develop a novel synthetic method. When the particles are formed in a reaction, the size of the particles is determined by the relative rates of two competitive processes, i.e., nucleation and the growth of nuclei to form large particles. The particle size of a freshly formed material is determined by the mechanism that predominates. In a reaction, if nucleation dominates, a material containing a large number of small particles are obtained, and if the growth predominates, a small number of large particles of the material are obtained. Altogether, it is desirable to design a reaction condition suitable for the formation of the product by altering the reaction temperature and solubility of reactants. Hence, we have developed a simple room temperature synthetic method to produce surfactant or template-free metal sulphides and selenides. Herewith, we have described the syntheses of $\mathrm{CuS}, \mathrm{Cu}_{2-z} \mathrm{Se}, \mathrm{Cu}_{2} \mathrm{~S}$ and $\mathrm{CdS}$ micron size particles and evolution of $\mathrm{BH}_{3}$ from the same reactions.

\section{Experimental}

\subsection{Materials and synthetic procedure}

The chemicals used in the syntheses, copper acetate $\left[\mathrm{Cu}\left(\mathrm{CH}_{3}\right.\right.$ $\left.\mathrm{COO})_{2} \cdot \mathrm{H}_{2} \mathrm{O}\right]\left(98.0 \%\right.$ purity), copper nitrate $\left[\mathrm{Cu}\left(\mathrm{NO}_{3}\right)_{2}\right.$. $\left.3 \mathrm{H}_{2} \mathrm{O}\right]\left(99.9 \%\right.$ purity), copper chloride $\left(\mathrm{CuCl}_{2} \cdot 2 \mathrm{H}_{2} \mathrm{O}\right)(99 \%$ purity), cadmium chloride $\left(\mathrm{CdCl}_{2}\right)$ (tech grade) and lithium borohydride $\left(\mathrm{LiBH}_{4}\right)$ (95\% purity) were purchased from
Sigma-Aldrich India and used as received. All the solvents were purified using standard procedures.

\subsection{Instruments and sample preparation}

Powder X-ray diffraction (PXRD) was carried out by using Bruker D8 X-ray diffractometer $[\lambda(\mathrm{Cu}-\mathrm{K} \alpha)=1.54 \AA]$ at scan rate of $1 \circ / \mathrm{min}$. The UV-Visible-NIR spectra of samples dispersed in methanol were recorded using Shimadzu UV$3600 / V$ is spectrophotometer. The Fourier transform infrared (FT-IR) spectra ( $\mathrm{KBr}$ pellet) were recorded using Jasco 5300 spectrophotometer. Field Emission Scanning Electron Microscopy (FESEM) images were obtained in Ultra 55 Carl Zeiss instrument; for this purpose the samples were dispersed in methanol and kept on glass plate. Transmission electron microscopy (TEM) images were obtained using FEI Technai $\mathrm{G}^{2} 20$ STEM instrument operated at an acceleration voltage of $200 \mathrm{kV}$. The TEM samples were prepared by dispersing the compound in methanol followed by sonication for $3 \mathrm{~min}$. Then, sonicated solution was dispersed immediately (otherwise it will settle down) on carbon coated nickel grids (200 mesh). ${ }^{31} \mathrm{P}\left\{{ }^{1} \mathrm{H}\right\},{ }^{1} \mathrm{H},{ }^{11} \mathrm{~B}$ NMR spectra were acquired in a Bruker Avance $400 \mathrm{MHz}$ using $85 \% \mathrm{HPO}_{4}, \mathrm{SiMe}_{4}$ and $\mathrm{BF}_{3}-$ ether, respectively as the standard references.

\subsection{Synthesis of CuS micro flowers}

In a typical reaction, sulphur (40 mg, $1.3 \mathrm{mmol})$ was dissolved in $15 \mathrm{~mL}$ of dry tetrahydrofuran (THF) in a $50 \mathrm{~mL}$ two neck RB flask, to that $\mathrm{LiBH}_{4}(59 \mathrm{mg}, 2.5 \mathrm{mmol})$ and $\mathrm{Cu}\left(\mathrm{CH}_{3} \mathrm{COO}\right)_{2} \cdot \mathrm{H}_{2} \mathrm{O}(250 \mathrm{mg}, 1.2 \mathrm{mmol})$ were added. The reaction mixture was stirred at room temperature under nitrogen atmosphere for $1 \mathrm{~h}$. Initially, the colour of the solution was dark brown, and after the completion of reaction it turned to dark green along with the evolution of gas(es). After one hour, volatile side products and solvent were removed by applying high vacuum. The obtained crude product was washed with methanol $(40 \mathrm{~mL})$ followed by THF $(40 \mathrm{~mL})$ to remove side products (copper acetate, lithium salt) and unreacted $\mathrm{S}$, and then centrifuged. The residue was dried under vacuum for 6 $\mathrm{h}$ to get a black powder of $\mathrm{CuS}$ micro flowers, which was characterized by PXRD and other techniques. Following the same procedure, the synthesis of $\mathrm{CuS}$ was carried out using two different precursors; $\mathrm{CuCl}_{2} \cdot 2 \mathrm{H}_{2} \mathrm{O}$ [250 mg, $1.5 \mathrm{mmol}$, sulphur (47 mg, $1.5 \mathrm{mmol}), \mathrm{LiBH}_{4}(47 \mathrm{mg}, 2.9 \mathrm{mmol}$ ), ] and $\mathrm{Cu}\left(\mathrm{NO}_{3}\right)_{2} \cdot 3 \mathrm{H}_{2} \mathrm{O}$. [250 mg, $1.0 \mathrm{mmol}$, sulphur (33 mg, 1.0 $\left.\mathrm{mmol}), \mathrm{LiBH}_{4}(45 \mathrm{mg}, 2.1 \mathrm{mmol})\right]$.

\subsection{Synthesis of $\mathrm{Cu}_{2} \mathrm{~S}$ nano/micro particles}

In a typical reaction, sulphur ( $20 \mathrm{mg}, 0.6 \mathrm{mmol})$ was dissolved in $15 \mathrm{~mL}$ of dry THF in a $50 \mathrm{~mL}$ two neck RB flask, to that $\mathrm{LiBH}_{4}(59 \mathrm{mg}, 2.5 \mathrm{mmol})$ and copper acetate $(250 \mathrm{mg}, 1.2$ $\mathrm{mmol}$ ) were added. The reaction mixture was stirred for 1 $\mathrm{h}$ at room temperature under the nitrogen atmosphere after that volatile side products and solvent were removed under vacuum. Obtained crude product was washed with methanol 
(40 $\mathrm{mL})$ and THF to remove side products and unreacted precursor and then centrifuged. The product was dried under vacuum for $6 \mathrm{~h}$ to obtain a brown powder of $\mathrm{Cu}_{2} \mathrm{~S}$ nano/micro particles.

\subsection{Synthesis of CdS micro particles}

In typical a reaction, sulphur (44 $\mathrm{mg}, 1.4 \mathrm{mmol}$ ) was dissolved in $15 \mathrm{~mL}$ of dry THF in a $50 \mathrm{~mL}$ two neck RB flask and then added $\mathrm{LiBH}_{4}(60 \mathrm{mg}, 2.8 \mathrm{mmol})$ and cadmium chloride (250 mg, $1.4 \mathrm{mmol}$ ). The reaction mixture was stirred for 1 $\mathrm{h}$ at room temperature under the nitrogen atmosphere after that volatile side products and solvent were removed under vacuum. Obtained crude product was washed with methanol $(40 \mathrm{~mL})$ and THF to remove side products and unreacted precursor and then centrifuged. The product was dried under vacuum $6 \mathrm{~h}$ to obtain a yellow powder of CdS micro particles.

\subsection{Synthesis of $\mathrm{Cu}_{2-\mathrm{z}}$ Se micro particles}

In a typical reaction, selenium powder $(49 \mathrm{mg}, 0.6 \mathrm{mmol})$ was added in $5 \mathrm{~mL}$ of dry THF in a $50 \mathrm{~mL}$ two neck RB flask, to that $\mathrm{LiBH}_{4}(59 \mathrm{mg}, 2.5 \mathrm{mmol})$ and copper acetate $(250 \mathrm{mg}$, $1.2 \mathrm{mmol}$ ) were added. The reaction mixture was stirred for $1 \mathrm{~h}$ at room temperature under the nitrogen atmosphere after that volatile side products and solvent were removed under vacuum. Obtained crude product was washed with methanol $(40 \mathrm{~mL})$ and THF to remove side products and unreacted precursor and then centrifuged. The product was dried under vacuum $6 \mathrm{~h}$ to obtain a black powder of $\mathrm{Cu}_{2-\mathrm{z}} \mathrm{Se}$ micro particles.

\subsection{Confirmation of $\mathrm{BH}_{3}$ by trapping as phosphine-borane complex}

To confirm the formation of $\mathrm{BH}_{3}$ in all above reactions, four separate reactions were conducted where $\mathrm{PPh}_{3}$ (721 mg, 2.7 mmol) was added to the mixture of $\mathrm{LiBH}_{4}$ and one of the metal sources $\left[\mathrm{Cu}\left(\mathrm{CH}_{3} \mathrm{COO}\right)_{2} \cdot \mathrm{H}_{2} \mathrm{O}, \mathrm{Cu}\left(\mathrm{NO}_{3}\right)_{2} \cdot 3 \mathrm{H}_{2} \mathrm{O}\right.$, $\mathrm{CuCl}_{2} \cdot 2 \mathrm{H}_{2} \mathrm{O}, \mathrm{CdCl}_{2}$ ], but in the absence of $\mathrm{S}$ and $\mathrm{Se}$. The reaction mixture was stirred at room temperature for $1 \mathrm{~h}$ under nitrogen atmosphere. The reaction mixture was filtered, and the solvent of the filtrate evaporated to obtain a crude product, which was dissolved in methanol and recrystallized to get pure $\mathrm{PPh}_{3}: \mathrm{BH}_{3}$ adduct. It was characterized by multinuclear NMR spectral data and single crystal X-ray diffraction studies. ${ }^{31} \mathrm{P}\left\{{ }^{1} \mathrm{H}\right\} \mathrm{NMR}\left(\delta \mathrm{ppm}\right.$ in $\left.\mathrm{CDCl}_{3}\right)$ : broad merged lines at 20.86 and 20.36. ${ }^{11} \mathrm{~B}$ NMR $\left(\delta\right.$ ppm in $\left.\mathrm{CDCl}_{3}\right):-37.94(\mathrm{~m})$. ${ }^{1} \mathrm{H} \mathrm{NMR}\left(\delta \mathrm{ppm}\right.$ in $\mathrm{CDCl}_{3}$ ): 7.63-7.44 (three set of multiplets, $15 \mathrm{H}, \mathrm{Ph}$ ), 1.3-0.92 (poorly resolved multiplet, $\left.3 \mathrm{H}, \mathrm{BH}_{3}\right)(\mathrm{Fig}-$ ures S1-S3 in Supplementary Information). The structure of $\mathrm{PPh}_{3}: \mathrm{BH}_{3}$ was confirmed by single crystal X-ray crystallography (Figure S4 in Supplementary Information). When the same reactions were conducted in the presence of sulphur a large amount of phosphine sulphide was also obtained due to due to sulphur bonding with phosphorous ${ }^{37}$ as confirmed from ${ }^{31} \mathrm{P}\left\{{ }^{1} \mathrm{H}\right\} \mathrm{NMR}$ spectrum (a peak at $\delta 43.34 \mathrm{ppm}$ ) (Figure $\mathrm{S} 2$ in SI).

\subsection{Procedure for conversion of acids to alcohols}

Acids to alcohols conversions via hydroboration were conducted similarly to metal sulphide/selenide syntheses by adding calculated quantity $(2.7 \mathrm{mmol})$ of each acid separately. The amount of acid to be added was decided by assuming evolution of one mole $\mathrm{BH}_{3}$ for each mole of $\mathrm{LiBH}_{4}$ used in the reactions. The reactants were added in THF sequentially as sulphur or selenium, $\mathrm{LiBH}_{4}$, metal sources and then organic acid. These reaction mixtures were stirred at room temperature for $3 \mathrm{~h}$ under nitrogen atmosphere.

The products were filtered and extracted with ether. The ether extract was washed with $3 \mathrm{~N} \mathrm{NaOH}(30 \mathrm{~mL})$ three times followed by brine solution and then dried over anhydrous $\mathrm{Na}_{2} \mathrm{SO}_{4}$. Evaporation of organic layer yielded alcohols. Structures of acids and corresponding alcohols are depicted in the Table S17 (in Supplementary Information). As determined by the ${ }^{1} \mathrm{H}$ NMR spectra of crude reaction mixtures, presumably, the majority of acid molecules were converted alcohol while remaining decomposed (Yield: $30-40 \%$ ). The formation of alcohols in these reactions was confirmed from the appearance of benzylic $-\mathrm{CH}_{2}$-peak around $4.6 \mathrm{ppm}$ in ${ }^{1} \mathrm{H}$ NMR spectra (Figure S18 in Supplementary Information).

\section{Results and Discussion}

\subsection{Formation of copper chalcogenides}

With the aim of producing organic surfactant free nano/micro particles, various metal sources were reacted with $\mathrm{LiBH}_{4}$ at room temperature in the presence of sulphur or selenium. These reactions yielded respective metal sulphide $\left(\mathrm{CuS}, \mathrm{Cu}_{2} \mathrm{~S}\right.$ and $\left.\mathrm{CdS}\right)$ or selenide $\left[\mathrm{Cu}_{2-\mathrm{z}} \mathrm{Se}(\mathrm{z}=0-0.28)\right]$ microparticles within $1 \mathrm{~h}$ (Table 1). All three copper sources, copper acetate $\left[\mathrm{Cu}\left(\mathrm{CH}_{3}\right.\right.$ $\left.\mathrm{COO})_{2} \cdot \mathrm{H}_{2} \mathrm{O}\right]$, copper nitrate $\left[\mathrm{Cu}\left(\mathrm{NO}_{3}\right)_{2} \cdot 3 \mathrm{H}_{2} \mathrm{O}\right]$, copper chloride $\left(\mathrm{CuCl}_{2} \cdot 2 \mathrm{H}_{2} \mathrm{O}\right)$, in the presence of sulphur (metal sources : $\mathrm{S}=1: 1$ ), on reactions with $\mathrm{LiBH}_{4}$ (two equivalents with respect to metal sources) yielded hexagonal covellite phase of $\mathrm{CuS}$. While the reaction of $\mathrm{LiBH}_{4}$ (two equivalents with respect to metal sources) with copper acetate $\left[\mathrm{Cu}\left(\mathrm{CH}_{3} \mathrm{COO}\right)_{2} \cdot \mathrm{H}_{2} \mathrm{O}\right]$ in the presence of lesser amount of sulphur $\left[\mathrm{Cu}\left(\mathrm{CH}_{3} \mathrm{COO}\right)_{2}\right.$. $\left.\mathrm{H}_{2} \mathrm{O}: \mathrm{S}=2: 1\right]$ yielded hexagonal- $\mathrm{Cu}_{2} \mathrm{~S}$. The same reaction in the presence of one equivalent of selenium $\left[\mathrm{Cu}\left(\mathrm{CH}_{3} \mathrm{COO}\right)_{2} \cdot \mathrm{H}_{2} \mathrm{O}: \mathrm{Se}=1: 1\right]$ yielded $\mathrm{Cu}_{2-\mathrm{z}} \mathrm{Se}(\mathrm{z}=$ $0-0.28$ ). A similar reaction of $\mathrm{CdCl}_{2}$ with $\mathrm{LiBH}_{4}$ (two equivalents) in the presence of sulphur $\left(\mathrm{CdCl}_{2}: \mathrm{S}=1: 1\right)$ yielded phase pure $\mathrm{CdS}$. These metal sulphides and selenide nano/micro particles were characterized by powder X-ray diffraction patterns and HRTEM. 
Table 1. Production of metal chalcogenides.

$x$ M-Salt $+y \mathrm{E}+n \mathrm{LiBH}_{4} \rightarrow \mathrm{M}_{x} \mathrm{E}_{y}+n \mathrm{BH}_{3} \uparrow+n$ Li-Salt

$\mathrm{M}=$ Metal; $\mathrm{E}=\mathrm{S}$, Se. Reaction condition: THF, rt, $1 \mathrm{~h}$.

\begin{tabular}{lccc}
\hline M Salt & E & Reaction stoichiometry & Product \\
\hline $\mathrm{Cu}_{\left(\mathrm{CH}_{3} \mathrm{COO}\right)_{2} \cdot \mathrm{H}_{2} \mathrm{O}}$ & $\mathrm{S}$ & $\mathrm{x}=1, \mathrm{y}=1, \mathrm{n}=2$ & $\mathrm{CuS}$ \\
$\mathrm{Cu}\left(\mathrm{NO}_{3}\right)_{2} \cdot 3 \mathrm{H}_{2} \mathrm{O}$ & $\mathrm{S}$ & $\mathrm{x}=1, \mathrm{y}=1, \mathrm{n}=2$ & $\mathrm{CuS}$ \\
$\mathrm{CuCl}_{2} \cdot 2 \mathrm{H}_{2} \mathrm{O}$ & $\mathrm{S}$ & $\mathrm{x}=1, \mathrm{y}=1, \mathrm{n}=2$ & $\mathrm{CuS}$ \\
$\mathrm{Cu}\left(\mathrm{CH}_{3} \mathrm{COO}\right)_{2} \cdot \mathrm{H}_{2} \mathrm{O}$ & $\mathrm{S}$ & $\mathrm{x}=1, \mathrm{y}=0.5, \mathrm{n}=2$ & $\mathrm{Cu}_{2} \mathrm{~S}$ \\
$\mathrm{CdCl}_{2}$ & $\mathrm{~S}$ & $\mathrm{x}=1, \mathrm{y}=1, \mathrm{n}=2$ & $\mathrm{CdS}$ \\
$\mathrm{Cu}_{\left(\mathrm{CH}_{3} \mathrm{COO}\right)_{2} \cdot \mathrm{H}_{2} \mathrm{O}}$ & $\mathrm{Se}$ & $\mathrm{x}=1, \mathrm{y}=0.5, \mathrm{n}=2$ & $\mathrm{Cu}_{2-\mathrm{z}} \mathrm{Se}(\mathrm{Z}=0-0.28)$
\end{tabular}

The selective production of any one of the polymorphic forms of copper sulphide is essential to use them for any device making. Interestingly, the standardized reaction scheme shown in Table 1 was useful to produce selectively $\mathrm{CuS}, \mathrm{Cu}_{2-\mathrm{z}} \mathrm{Se}(\mathrm{z}=0-0.28), \mathrm{Cu}_{2} \mathrm{~S}$ and $\mathrm{CdS}$ nano/micro particles at room temperature. Besides, hydrated water in metal sources did not seem to affect the preferred products. Since the method developed here was reproducible, inexpensive and consume very less time they have the potential to be used for the production of various metal sulphides.

\section{$3.2 \mathrm{BH}_{3}$ evaluation and in-situ organic reactions}

In organic, inorganic and materials chemistry, several reactions are known where $\mathrm{LiAlH}_{4}, \mathrm{LiBH}_{4}, \mathrm{NaBH}_{4}$, and $\mathrm{KBH}_{4}$ are used as hydride sources and reducing agents. ${ }^{21}$ However, only a few reports explained the fate of $\mathrm{Al}$ and $\mathrm{B}$ presented in these reducing agents after the reactions. ${ }^{22}$ In the earlier reports, ${ }^{13 c, 23}$ we have established the evolution $\mathrm{BH}_{3}$ in the reaction of $\mathrm{LiBH}_{4}$ with $\mathrm{ZnCl}_{2}$ or $\mathrm{PbNO}_{3}$. Similarly, in the present study, all reactions involving $\mathrm{LiBH}_{4}$ and various metal sources yielded the $\mathrm{BH}_{3}$ gas along with metal chalcogenides. The formation of $\mathrm{BH}_{3}$ was confirmed by trapping it with $\mathrm{PPh}_{3}$ as $\mathrm{BH}_{3}: \mathrm{PPh}_{3}$ adduct and subsequent characterization by spectral data and single crystal X-ray diffraction studies (Figures S1-S4 in Supplementary Information).

The mixture of $\mathrm{NaBH}_{4} / \mathrm{I}_{2}$ is known to produce $\mathrm{BH}_{3}$ and the utility of this reaction has been well established. ${ }^{24}$ The borohydrides $\left(\mathrm{BH}_{4}^{-}\right)$are used as hydride source in the variety of organic reactions. ${ }^{22 b, 25}$ Methods of enhancement of reactivity and selectivity of borohydride for applications in organic synthesis have been studied thoroughly. ${ }^{26}$ To confirm further, when a few organic acids (aromatic and aliphatic acids) were added to the reaction of $\mathrm{LiBH}_{4}$ and metal sources $\left[\mathrm{Cu}\left(\mathrm{CH}_{3} \mathrm{COO}\right)_{2} \cdot \mathrm{H}_{2} \mathrm{O}, \mathrm{Cu}\left(\mathrm{NO}_{3}\right)_{2} \cdot 3 \mathrm{H}_{2} \mathrm{O}, \mathrm{CuCl}_{2}\right.$. $2 \mathrm{H}_{2} \mathrm{O}, \mathrm{CdCl}_{2}$ ], the hydroboration reaction occurred quickly utilizing the in situ generated $\mathrm{BH}_{3}$. Subsequent

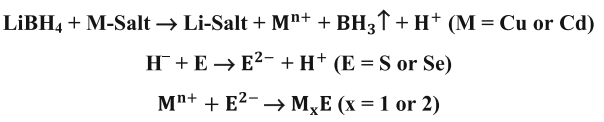

Scheme 1. Plausible reaction pathway for the formation of metal chalcogenides and $\mathrm{BH}_{3}$.

hydrolysis yielded the corresponding alcohols (yield: $30-40 \%$ ). This functional group transformation is possible via hydroboration. Altogether, the formation of $\mathrm{BH}_{3}$ in these reactions appears to be common in the reactions of metal borohydrides with metal halides and metal salts. Formation of gaseous side product eased the removal of boron from the reaction.

The formation of metal chalcogenides and $\mathrm{BH}_{3}$ in these reactions can be explained as follows. A few reports explained the formation $\mathrm{NaHE}(\mathrm{E}=\mathrm{S}, \mathrm{Se}, \mathrm{Te})$ in the reaction of $\mathrm{NaBH}_{4}$ in the presence of water. ${ }^{22 \mathrm{e}}$ The NaHE subsequently reacted with metal chlorides yielding metal chalcogenides. However, as mentioned earlier, the evolution $\mathrm{BH}_{3}$ in the reaction of $\mathrm{LiBH}_{4}$ with $\mathrm{ZnCl}_{2}$ or $\mathrm{PbNO}_{3}$ and $\mathrm{NaBH}_{4}$ with $\mathrm{CoCl}_{2}$ and $\mathrm{I}_{2}$ are also documented. ${ }^{13 c, 23,25}$ Further, we performed control reactions wherein $\mathrm{LiBH}_{4}$ was reacted with anhydrous metal sources $\left(\mathrm{Cu}\left(\mathrm{CH}_{3} \mathrm{COO}\right)_{2}, \mathrm{Cu}\left(\mathrm{NO}_{3}\right)_{2}\right.$, and $\left.\mathrm{CuCl}_{2}\right)$ in the absence of chalcogens. All these reaction also liberated $\mathrm{BH}_{3}$. The reactions of $\mathrm{LiBH}_{4}$ with hydrated metal sources accelerated the reactions. Therefore, the sequence of reactions might be as shown in Scheme 1. First, $\mathrm{LiBH}_{4}$ reacted with metal sources forming lithium salts $\left(\mathrm{LiCl}, \mathrm{LiNO}_{3}\right.$, and $\left.\mathrm{LiOAc}\right)$, and then hydride ions from $\left(\mathrm{BH}_{4}^{-}\right.$reacted with the metal sources to liberate $\mathrm{BH}_{3}$ and $\mathrm{H}^{-}$.

\subsection{Characterization of metal chalcogenides}

The PXRD (Figure 1) patterns of $\mathrm{CuS}$ (JCPDS \#060464, $\mathrm{a}=3.792 \AA$ and $\mathrm{c}=16.344 \AA$ ) showed the formation hexagonal covellite phase in all three reactions. Absence of other characteristic peaks corresponding 
to copper acetate, copper oxide, sulphur and $\mathrm{Cu}_{2} \mathrm{~S}$, or any other phase of $\mathrm{CuS}$ confirmed the phase purity of the products. Interestingly, PXRD pattern of the product from 2:1 $\left[\mathrm{Cu}\left(\mathrm{CH}_{3} \mathrm{COO}\right)_{2} \cdot \mathrm{H}_{2} \mathrm{O}: \mathrm{S}=2: 1\right]$ reaction showed a selective formation of hexagonal$\mathrm{Cu}_{2} \mathrm{~S}$ (JCPDS \#89-2670), (Figure S5 in Supporting Information). The selective formation of either $\mathrm{CuS}$ or $\mathrm{Cu}_{2} \mathrm{~S}$ in the above reaction confirmed the stoichiometry control in the reaction. PXRD patterns of $\mathrm{Cu}_{2-z} \mathrm{Se}$ $(\mathrm{z}=0-0.28)$ (JCPDS \#06-0680) (Figure S6 in Supporting Information) and CdS (JCPDS \#89-0440) (Figure S7 in SI) showed the formation of pure fcc phases of both microparticles. Peaks in the diffraction pattern were broadened in all cases due to the nano size of the particles. The Vis-NIR spectrum of $\mathrm{CuS}$ and $\mathrm{Cu}_{2} \mathrm{~S}$ dispersed in methanol showed the absorption edge at $683 \mathrm{~nm}$ and $568 \mathrm{~nm}$ respectively (Figures S8-S9 in SI). Both microparticles had absorption band spanning into NIR

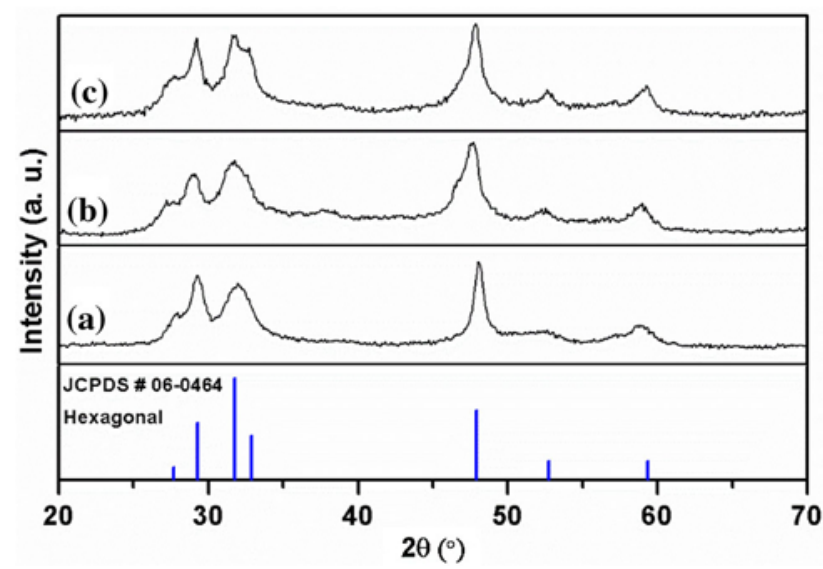

Figure 1. Powder X-ray diffraction (PXRD) patterns of $\mathrm{CuS}$ obtained (a) $\mathrm{CuCl}_{2}$, (b) $\mathrm{Cu}(\mathrm{OAc})_{2}$, (c) $\mathrm{Cu}\left(\mathrm{NO}_{3}\right)_{2}$ as metal sources. region. The materials with NIR absorption are reported to be useful in photoacoustic contrast agent for deep tissue imaging and Photothermal ablation therapy for cancer cells. ${ }^{27}$

In last few years, there has been focus on the synthesis of $\mathrm{CuS}$ particles existing in different shapes such as nanoflakes, nanotubes, microspheres, flower-like structures, nanowires, nanorods, urchin-like structures, and nanoribbons. ${ }^{28-33}$ In these reactions, the morphology of products obtained under identical conditions was varying with the change of metal sources (Table 2). Typical FESEM image (Figures 2a, b) revealed the formation of "rose-flower" like architecture when copper acetate was used in the reaction. These microflowers were constituted through self-assembly of numerous nanoflakes. The width of the flakes ranged within $5-10 \mathrm{~nm}$ and length of flakes were within $40-200 \mathrm{~nm}$. When copper chloride was the metal source, aggregated $\mathrm{CuS}$ particles having "cauliflower" like architecture were formed (size: 50-200 nm, (Figures 2c, d). When copper nitrate was used, randomly shaped aggregates of $\mathrm{CuS}$ particles with a size range of $20-40 \mathrm{~nm}$ (Figures $2 \mathrm{e}, \mathrm{f})$ were obtained. All these microflowers consisted of nano crystallites. The average sizes of nano crystallites calculated using Scherrer formula is around 30 $\mathrm{nm}\left[31.7 \mathrm{~nm}\right.$ (when metal source was $\mathrm{CuCl}_{2}$ ); $30.1 \mathrm{~nm}$ (when metal source was $\mathrm{Cu}(\mathrm{OAC})_{2} ; 30.1 \mathrm{~nm}$ (when metal source was $\mathrm{Cu}\left(\mathrm{NO}_{3}\right)_{2}$ ] (Table $\mathrm{S} 2$ in Supporting Information).

Images of $\mathrm{Cu}_{2} \mathrm{~S}$ particles showed aggregation of "peanut-shaped" particles (Figures 2g, h). Similarly, many $\mathrm{Cu}_{2-\mathrm{z}} \mathrm{Se}$ particles were seen plate-like in FESEM as while some of were having hexagons (Figure S10 in SI). CdS particles were an aggregation of spherical particles with size range 20-30 nm (Figure S11 in SI).

Table 2. Reaction condition and particles sizes of various Products ${ }^{\mathrm{a}}$.

\begin{tabular}{|c|c|c|c|}
\hline Metal source & $\begin{array}{l}\text { Concentration of metal } \\
\text { sources in (Molarity) }\end{array}$ & Product & Particles shapes and sizes \\
\hline $\mathrm{Cu}\left(\mathrm{CH}_{3} \mathrm{COO}\right)_{2} \cdot \mathrm{H}_{2} \mathrm{O}$ & 0.083 & $\mathrm{CuS}$ & $\begin{array}{l}\text { nano flakes which self-assembled to } \\
\text { form rose flowers architecture } \\
5-10 \mathrm{~nm} \text { (flake width) } 40-200 \mathrm{~nm} \\
\text { (flake length) }\end{array}$ \\
\hline $\mathrm{Cu}\left(\mathrm{NO}_{3}\right)_{2} \cdot 3 \mathrm{H}_{2} \mathrm{O}$ & 0.098 & $\mathrm{CuS}$ & Nanoparticles $20-40 \mathrm{~nm}$ \\
\hline $\mathrm{CuCl}_{2} \cdot 2 \mathrm{H}_{2} \mathrm{O}$ & 0.069 & $\mathrm{CuS}$ & Cauliflower shape $100-200 \mathrm{~nm}$ \\
\hline $\mathrm{Cu}\left(\mathrm{CH}_{3} \mathrm{COO}\right)_{2} \cdot \mathrm{H}_{2} \mathrm{O}$ & 0.083 & $\mathrm{Cu}_{2} \mathrm{~S}$ & $\begin{array}{l}\text { Peanut shaped 50-100 nm (length) } \\
\text { 20-30 nm (width) }\end{array}$ \\
\hline $\mathrm{Cu}\left(\mathrm{CH}_{3} \mathrm{COO}\right)_{2} \cdot \mathrm{H}_{2} \mathrm{O}$ & 0.083 & $\mathrm{Cu}_{2-\mathrm{z}} \mathrm{Se}$ & \\
\hline $\mathrm{CdCl}_{2}$ & 0.083 & $\mathrm{CdS}$ & Spherical nanoparticles $20-30 \mathrm{~nm}$ \\
\hline
\end{tabular}

${ }^{\mathrm{a}}$ reaction time 1 hour, ${ }^{\mathrm{b}}$ solvent THF. 

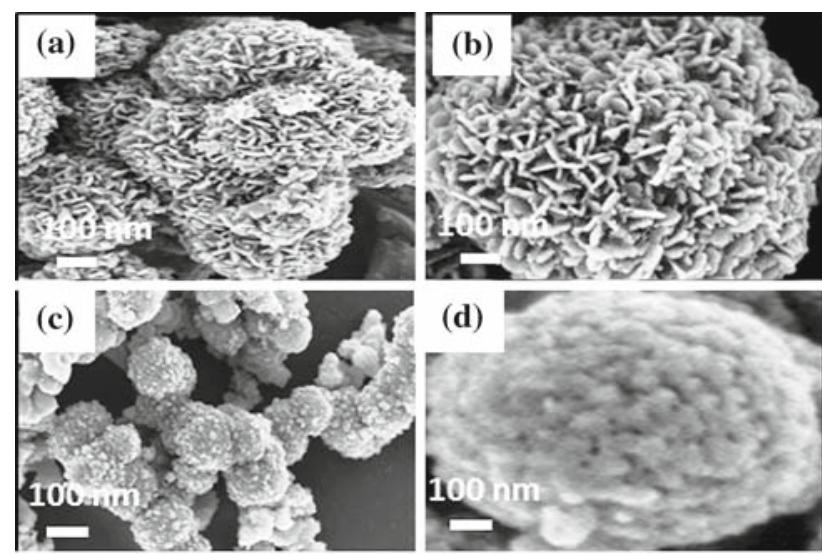

(d)
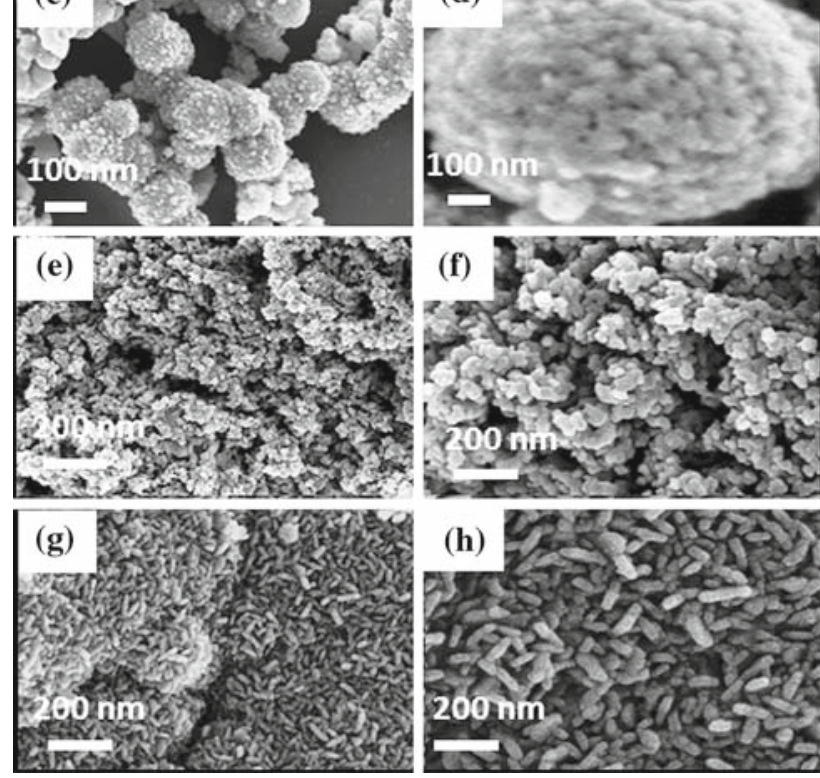

(h)

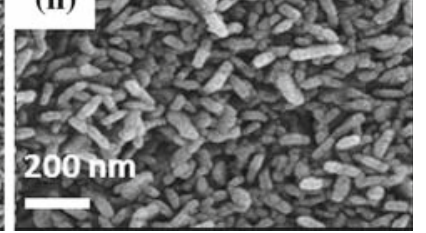

Figure 2. FESEM images of CuS: (a, b) rose-flower like architecture obtained when copper acetate was metal source, (c, d) cauliflower like aggregation obtained from copper chloride, (e, f) Randomly shaped nanoparticles were obtained from copper nitrate. $(\mathrm{g}, \mathrm{h})$ peanut shaped $\mathrm{Cu}_{2} \mathrm{~S}$ nanoparticles.

Figure 3 depicts TEM and HRTEM images along with SAED patterns. Morphologies and sizes seen in TEM images (Figure 3a) of CuS obtained using three different copper sources were consistent with that observed in FESEM. SAED patterns of CuS nano/micro particles obtained in reactions where copper acetate was metal

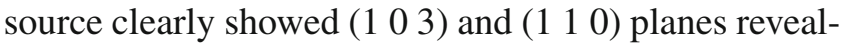
ing the crystalline nature of $\mathrm{CuS}$ nanoflakes. HRTEM images (Figure 3c) clearly showed a lattice spacing of $0.28 \mathrm{~nm}$, which was consistent with the distance between the $\left(\begin{array}{lll}1 & 0 & 3\end{array}\right)$ lattice planes observed in pure hexagonal covellite phase of CuS (JCPDS \#06-0464). Similarly, the SAED patterns and HRTEM of CuS obtained from two other reactions also showed lattice planes $\left(\begin{array}{lll}1 & 0 & 3\end{array}\right)$ and $\left(\begin{array}{lll}1 & 1 & 0\end{array}\right)$ matching with PXRD patterns of $\mathrm{CuS}$ hexagonal covellite phase. TEM analysis of $\mathrm{Cu}_{2} \mathrm{~S}$ showed a peanut like nanostructure of length 50$100 \mathrm{~nm}$ and width 20-30 nm (Figures 3j, k, 1). SAED and HRTEM images clearly showed a lattice spacing of 0.19 $\mathrm{nm}$, which was consistent with the distance between the (1 110$)$ lattice planes.
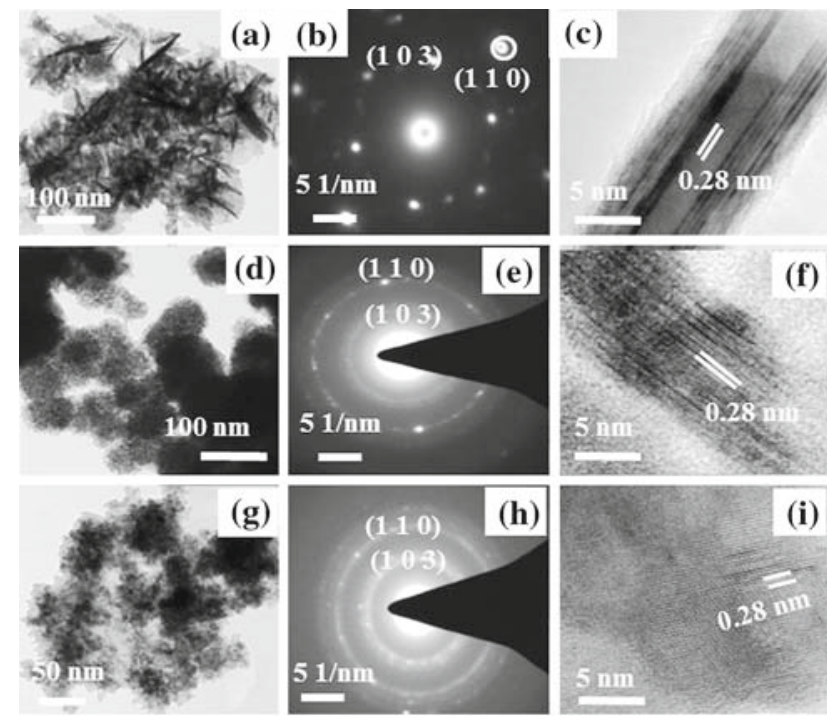

(f)
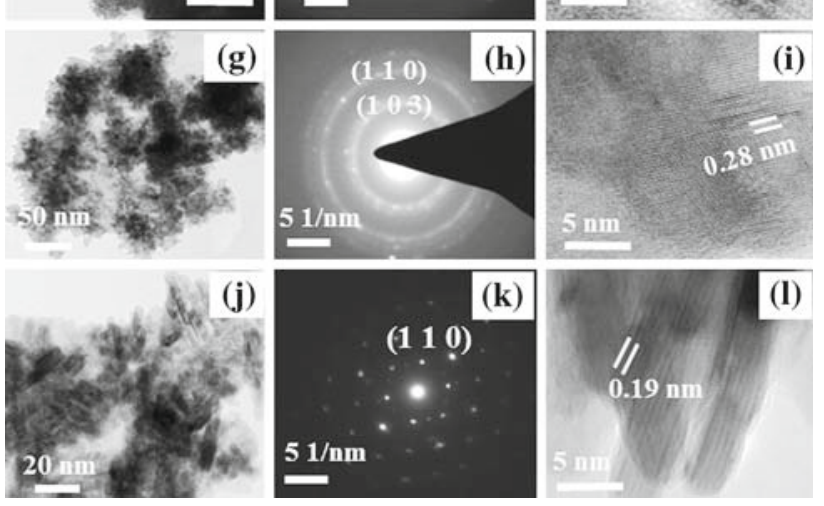

Figure 3. TEM image of $\mathrm{CuS}$, rose flowers architecture (a), SAED (b), HRTEM (c) obtained from copper acetate. Cauliflower-like nano structure (d), SAED (e), HRTEM (f) obtained from copper chloride. Randomly shaped nanoparticles (g), SAED (h), HRTEM (i) obtained from copper nitrate and TEM image of $\mathrm{Cu}_{2} \mathrm{~S}$ peanut shaped nanoparticles (j), $\operatorname{SAED}(\mathrm{k}), \operatorname{HRTEM}(\mathrm{l})$.

\subsection{Formation of surfactant free nanoparticle and their purity}

It is necessary to avoid heterogeneous impurities to achieve full utilization ${ }^{19}$ of properties of the hierarchical superstructure. Since surfactants molecules or capping agents do not contribute to the application requirements, they are considered as impurities of nano/micro particles. Hence, the purity of metal chalcogenides was collectively assessed by elemental analysis, PXRD pattern and FT-IR spectra. Elemental analyses of the particles reported here $\left(\mathrm{CuS} \mathrm{Cu}_{2} \mathrm{~S}, \mathrm{CdS}\right.$ and $\left.\mathrm{Cu}_{2-z} \mathrm{Se}\right)$ using Energy Dispersive X-ray Spectroscopy (EDAX) (Figures S12-15 in Supporting Information) proved the presence of the respective elements $(\mathrm{Cu}, \mathrm{Cd}, \mathrm{S}$, and $\mathrm{Se})$ in the materials. The results were consistent for various samples of every material and confirmed the absence of carbonaceous impurities.

Further, PXRD spectra did not show any amorphous regions corresponding to any organic materials. Clear PXRD patterns matching the targeted materials and the absence of any other compounds (within the detectable limit of PXRD) or other phases confirmed the purity 
of materials reported here. Further confirmation about the absence of organic moieties was obtained from FT-IR spectra. The FT-IR spectra (Figure S16 in Supporting Information) of $\mathrm{CuS}, \mathrm{Cu}_{2} \mathrm{~S}, \mathrm{CdS}$ and $\mathrm{Cu}_{2-\mathrm{z}} \mathrm{Se}$ obtained from the reactions described here showed no signal for any organic impurity confirming the absence of any organic molecules around the particles. Thus, our reactions yielded the nanomaterials without organic molecules surrounding it.

Agglomeration is a common phenomenon of metal nanoparticles which induces the growth of nuclei leading to the formation of bigger particles. Capping agents are required to ensure colloid stability during synthesis of nanoparticles. Interestingly, it was observed that the metal sulphide nano/micro particles, obtained in the present as well as in the past studies, did not agglomerate. ${ }^{13}$ Xie and co-workers ${ }^{34}$ suggested the formation of thermodynamically stable structure under right growing conditions, which can yield nanoparticles. Thus the formation nanoparticles can be explained by invoking the necessity of ripening phenomenon for the particle growth. The digestion is a much-needed process practiced in gravimetric analyses to obtain large crystals of metal sulphides, sulphates and salts where there are no metallic bonds. The Ostwald ripening process $^{35}$ helps the growth of particles during digestion. This observation gives a clue that if the condition is not favouring the growth, the particles will remain in nano-regime. Therefore, in any reaction to produce nanoparticles, it is necessary to create a condition favouring the nucleation instead the growth of particles.

Von Weimarn's theory ${ }^{36}$ of relative supersaturation and subsequent studies explained nucleation vs. particles growth as factors deciding the sizes of particles formed in a reaction. According to the theory, increased solubility of products and elevated temperature would yield particles of bigger sizes. Consequently, the saturated conditions, room temperature reactions, and fast reactions should not support the growth of the nucleus but should produce smaller particles. The reaction conditions and particle sizes of various products obtained are listed in Table 2. The data in the table showcases the influence of reaction condition on the size of particles. Since both the starting materials and products described in the present reactions were only sparingly soluble in THF, the room temperature reactions favoured thermodynamically stable sizes for the particles. However, since there was no other factor supporting the growth of nuclei, these metal sulphide particles remained in nano size after synthesis. Those nano crystallites selfassembled and formed rigid microflower. ${ }^{13 \mathrm{~b}}$ Thus, the method described here is useful to produce nano/micro particles without surfactants or any other templates. Nevertheless, the method needs optimization to produce uniform particle size.

\section{Conclusions}

A versatile method for the syntheses of organic free $\mathrm{CuS}, \mathrm{Cu}_{2} \mathrm{~S}, \mathrm{CdS}$ and $\mathrm{Cu}_{2-\mathrm{z}} \mathrm{Se}$ nano/microparticles at room temperature within one hour is described. All these materials were characterized thoroughly using PXRD patterns and electron microscopic images. The supersaturated condition and the strong reactivity of $\mathrm{LiBH}_{4}$ drove the formation of metal chalcogenide nano/micro particles. After the synthesis, the particles remained in nano sizes as long as the compounds were stable. The method was reproducible and can be extended for the production of many metal sulphides.

The reduction reactions producing metal chalcogenide microparticles also yielded borane $\left(\mathrm{BH}_{3}\right)$, which was characterized by trapping it with $\mathrm{PPh}_{3}$. Evolution of $\mathrm{BH}_{3}$ in the reactions of $\mathrm{LiBH}_{4}$ with various metal sources established the formation of it as a regular phenomenon. The morphology of $\mathrm{CuS}$ particles obtained in these reactions was varying with a change of metal source used in the reaction. To the best of our knowledge, this is the first observation of metal source dependent morphology of nano/microparticles obtained under identical reaction condition.

\section{Supplementary Information (SI)}

NMR spectra of $\mathrm{Ph}_{3} \mathrm{P}, \mathrm{PXRD}$ spectra of $\mathrm{Cu}_{2} \mathrm{~S}, \mathrm{Cu}_{2-\mathrm{z}} \mathrm{Se}, \mathrm{CdS}$, UV-Vis-NIR spectra of $\mathrm{CuS}$ and $\mathrm{Cu}_{2} \mathrm{~S}$, EDAX spectra of $\mathrm{CuS}$, $\mathrm{Cu}_{2} \mathrm{~S}, \mathrm{Cu}_{2-\mathrm{z}} \mathrm{Se}, \mathrm{CdS}$, FESEM images of $\mathrm{Cu}_{2-\mathrm{z}} \mathrm{Se}, \mathrm{CdS}$, FTIR spectrum of $\mathrm{CuS},{ }^{1} \mathrm{H}$ NMR spectrum of reaction mixture and table containing reactions of acid to alcohol conversion using in situ generated $\mathrm{BH}_{3}$ are available as Supplementary Information at www.ias.ac.in/chemsci.

\section{Acknowledgements}

The authors thank the Centre for Nanotechnology at the University of Hyderabad for the TEM facility. SNG acknowledges UGC -India for doctoral fellowship. The work is supported by DST-SERB of India under project No: SB/S1/IC47/2013.

\section{References}

1. (a) Wang XL and Swihart M T 2015 Controlling the Size, Shape, Phase, Band Gap, and Localized Surface Plasmon Resonance of $\mathrm{Cu}_{2-\mathrm{x}} \mathrm{S}$ and $\mathrm{Cu}_{\mathrm{x}} \mathrm{In}_{\mathrm{y}} \mathrm{S}$ Nanocrystals Chem. Mater. 27 1786; (b) Foglia S, Suber L and Righini M 
2001 Size tailoring of CdS nanoparticles by different colloidal chemical techniques Colloid. Surface. A 1773

2. Santra S, Yang H, Stanley J T, Holloway P H, Moudgil B M, Walterd G R and Mericle A 2005 Rapid and effective labelling of brain tissue using TAT-conjugated $\mathrm{CdS}$ : $\mathrm{Mn} / \mathrm{ZnS}$ quantum dots Chem. Commun. 253144

3. Chaudhary S, Ozkan M and Chan W C W 2004 Trilayer hybrid polymer-quantum dot light-emitting diodes Appl. Phys. Lett. 842925

4. Song W S and Yang H 2012 Efficient white-lightemitting diodes fabricated from highly fluorescent copper indium sulphide core/shell quantum dots Chem. Mater. 241961

5. Tan Z, Zhang F, Zhu T and Xu J 2007 Bright and coloursaturated emission from blue light-emitting diodes based on solution-processed colloidal nanocrystal quantum dots Nano Lett. 73803

6. Shalom M, Ruhle S, Hod I, Yahav S and Zaban A 2009 Energy level alignment in $\mathrm{CdS}$ quantum dot sensitized solar cells using molecular dipoles J. Am. Chem. Soc. 1319876

7. Wang P, Wang L, Ma B, Li B and Qiu Y $2006 \mathrm{TiO}_{2}$ surface modification and characterization with nanosized $\mathrm{PbS}$ in dye-sensitized solar cells J. Phys. Chem. B $\mathbf{1 1 0}$ 14406

8. Lee H, Yoon S W, Kim E J and Park J 2007 In-situ growth of copper sulphide nanocrystals on multiwalled carbon nanotubes and their application as novel solar cell and amperometric glucose sensor materials Nano Lett. 7778

9. Mishra N, Mukherjee B, Xing G, Chakrabortty S, Guchhait A and Lim J Y 2016 Cation exchange synthesis of uniform $\mathrm{PbSe} / \mathrm{PbS}$ core/shell tetra-pods and their use as near-infrared photodetectors Nanoscale 814203

10. Koch D F A and McIntyre R J 1976 The application of reflectance spectroscopy to a study of the anodic oxidation of cuprous sulphide J. Electroanal. Chem. 71285

11. Grozdanov I and Najdoski M 1995 Optical and electrical properties of copper sulphide films of variable composition J. Solid State Chem. 114469

12. (a) Roy P, Mondal K and Srivastava S K 2008 Synthesis of twinned $\mathrm{CuS}$ nanorods by a simple wet chemical method Cryst. Growth Des. 8 1530; (b) Roy P and Srivastava S K 2007 Low-temperature synthesis of CuS nanorods by simple wet chemical method Mater. Lett. 61 1693; (c) Hsu S, On K and Tao A R 2011 Localized surface plasmon resonances of anisotropic semiconductor nanocrystals J. Am. Chem. Soc. 133 19072; (d) Bryks W, Wette M, Velez N, Hsu S and Tao A R 2014 Supramolecular precursors for the synthesis of anisotropic $\mathrm{Cu}_{2} \mathrm{~S}$ nanocrystals J. Am. Chem. Soc. 136 6175; (e) Hsu S, Bryks W and Tao A R 2012 Effects of Carrier Density and Shape on the Localized Surface Plasmon Resonances of $\mathrm{Cu}_{2-x} \mathrm{~S}$ Nanodisks Chem. Mater. 24 3765; (f) Hsu S, Ngo C and Tao A R 2014 Tuneable and directional plasmonic coupling within semiconductor nanodisk assemblies Nano Lett. 14 2372

13. (a) Kumar B G and Muralidharan K 2011 Hexamethyldisilazane-assisted synthesis of indium sulphide nanoparticles J. Mater. Chem. 30 11271; (b) Kumar B G and Muralidharan K 2013 Organic-Free Self-Assembled Copper Sulphide Microflowers Eur. J.
Inorg. Chem. 32 2102; (c) Gottapu S N and Muralidharan K 2016 Room temperature synthesis of organic surfactant-free $\mathrm{PbS}$ and $\mathrm{PbSe}$ nanoparticles exhibiting NIR absorption New J. Chem. 40832

14. Li B, Xie Y and Xue Y 2007 Controllable synthesis of $\mathrm{CuS}$ nanostructures from self-assembled precursors with biomolecule assistance J. Phys. Chem. C 11112181

15. Wang W, Germanenko I and El-Shal M S 2002 Roomtemperature synthesis and characterization of nanocrystalline $\mathrm{CdS}, \mathrm{ZnS}$, and $\mathrm{Cd}_{\mathrm{x}} \mathrm{Zn}_{1-\mathrm{x}} \mathrm{S}$ Chem. Mater. 143028

16. Chung J-S and Sohn H-J 2002 Electrochemical behaviours of $\mathrm{CuS}$ as a cathode material for lithium secondary batteries J. Power Source 108226

17. Mao G, Dong W, Kurth D G and Mohwald H 2004 Synthesis of copper sulphide nanorod arrays on molecular templates Nano Lett. 4249

18. (a) Gao L, Wang E, Lian S, Kang Z, Lan Y and Wu D 2004 Microemulsion-directed synthesis of different CuS nanocrystals Solid State Commun. 130309

19. (a) Kumar P, Gusain M and Nagarajan R 2012 Solventmediated room temperature synthesis of highly crystalline $\mathrm{Cu}_{9} \mathrm{~S}_{5}\left(\mathrm{Cu}_{1.8} \mathrm{~S}\right), \mathrm{CuSe}, \mathrm{PbS}$, and $\mathrm{PbSe}$ from their elements Inorg. Chem. 51 7945; (b) Kumar P, Gusain M and Nagarajan R 2011 Synthesis of $\mathrm{Cu}_{1.8} \mathrm{~S}$ and $\mathrm{CuS}$ from copper-thiourea containing precursors; anionic $\left(\mathrm{Cl}^{-}\right.$, $\mathrm{NO}_{3}^{-}, \mathrm{SO}_{4}^{2-}$ ) influence on the product stoichiometry Inorg. Chem. 503065

20. (a) Kovalenko M V, Scheele M and Talapin D V Colloidal nanocrystals with molecular metal chalcogenide surface ligands Science 324 1417; (b) Talapin D V, Lee J S, Kovalenko M V and Shevchenko E V 2010 Prospects of colloidal nanocrystals for electronic and optoelectronic applications Chem. Rev. 110 389; (c) Kilina S, Ivano S and Tretiak S 2009 Effect of surface ligands on optical and electronic spectra of semiconductor nanoclusters $J$. Am. Chem. Soc. 1317717

21. (a) Giannis A and Sandhoff K $1989 \quad \mathrm{LiBH}_{4}$ $\left(\mathrm{NaBH}_{4}\right) / \mathrm{Me}_{3} \mathrm{SiCl}$, an unusually strong and versatile reducing agent Angew. Chem. Int. Ed. Engl. 28 218; (b) Gemal A L and Luche J-L 1981 Lanthanoids in organic synthesis. 6. Reduction of alpha-enones by sodium borohydride in the presence of lanthanoid chlorides: synthetic and mechanistic Aspects J. Am. Chem. Soc. 103 5454; (c) Vajo J J and Skeith S L 2005 Reversible storage of hydrogen in destabilized $\mathrm{LiBH}_{4}$ J. Phys. Chem. B 109 3719; (d) Zhang L, Shen $\mathrm{X}$ and Liang H 2010 A mild phosphine-free synthesis of alkylamine-capped CdSe nanocrystals J. Nanosci. Nanotechnol. 10 4979; (e) Ramasamy K, Nejo A O, Ziqubu N, Rajasekhar P V S R, Nejo A A, Revaprasadu N and Paul O'Brien 2011 A new route to lead chalcogenide nanocrystals Eur. J. Inorg. Chem. 5196; (f) Moloto N, Moloto M J, Coville N J and Sinha Ray S 2009 Optical and structural characterization of nickel selenide nanoparticles synthesized by simple methods J. Cryst. Growth 311 3924; (g) Oluwafemi O S and Revaprasadu N 2008 A new synthetic route to organically capped cadmium selenide nanoparticles New J. Chem. 32 1432; (h) Kandasamy K, Singh H B and Kulahreshtha S K 2009 Synthesis and characterization of CdS and CdSe nanoparticles prepared from novel intramolecularly stabilized single-source precursors J. Chem. Sci. 121 
293; (i) Jain V K 2006 Synthesis and characterization of single-source molecular precursors for the preparation of metal chalcogenides J. Chem. Sci. 118547

22. (a) Sudeep P K, Page Z and Emrick T 2008 PEGylated silicon nanoparticles: synthesis and characterization Chem. Commun. 6126; (b) Cheng X, Gondosiswanto R, Ciampi S, Reeceb P J and Gooding J J 2012 One-pot synthesis of colloidal silicon quantum dots and surface functionalization via thiol-ene click chemistry Chem. Commun. 48 11874; (c) Wang J, Sun S, Peng F, Cao L and Sun L 2011 Efficient one-pot synthesis of highly photoluminescent alkyl-functionalised silicon nanocrystals Chem. Commun. 47 4941; (d) Rosso-Vasic M, Spruijt E, Popovic Z, Overgaag K, Lagen B V, Grandidier B, Vanmaekelbergh D, Nguez-Gutierrez D D, Cola L D and Zuilhof H 2009 Amine-terminated silicon nanoparticles: synthesis, optical properties and their use in bioimaging J. Mater. Chem. 195926

23. Ghanta S R, Rao M H and Muralidharan K 2013 Singlepot synthesis of zinc nanoparticles, borane $\left(\mathrm{BH}_{3}\right)$ and closo-dodecaborate $\left(\mathrm{B}_{12} \mathrm{H}_{12}\right)^{2-}$ using $\mathrm{LiBH}_{4}$ under mild conditions Dalton Trans. 428420

24. (a) Bhaskar Kanth J V and Periasamy M 1991 Selective reduction of carboxylic acids into alcohols using sodium borohydride and iodine J. Org. Chem. 56 5964; (b) Bhanu Prasad A S, Bhaskar Kanth J V and Periasamy M 1992 Convenient methods for the reduction of amides, nitriles, carboxylic esters, acids and hydroboration of alkenes using $\mathrm{NaBH}_{4} / \mathrm{I}_{2}$ system Tetrahedron 48 4623

25. (a) Giannis A and Sandhoff $\mathrm{K} 1989 \mathrm{LiBH}_{4}$ $\left(\mathrm{NaBH}_{4}\right) / \mathrm{Me}_{3} \mathrm{SiCl}$, an unusually strong and versatile reducing agent Angew. Chem. Int. Ed. Engl. 28 218; (b) Vajo J J and Skeith S L 2005 Reversible storage of hydrogen in destabilized $\mathrm{LiBH}_{4}$ J. Phys. Chem. B 109 3719

26. (a) Satyanarayana N and Periasamy M 1984 Hydroboration or hydrogenation of alkenes with $\mathrm{CoCl}_{2}$ $\mathrm{NaBH}_{4}$ Tetrahedron Lett. 25 2501; (b) Periasamy M and Thirumalaikumar M 2000 Methods of enhancement of reactivity and selectivity of sodium borohydride for applications in organic synthesis J. Organometallic Chem. 609137

27. (a) Liu R, Jing L, Peng D, Li Y, Tian J and Dai Z 2015 Manganese (II) Chelate Functionalized Copper Sulfide Nanoparticles for Efficient Magnetic Resonance/Photoacoustic Dual-Modal Imaging Guided Photothermal Therapy Theranostics 5 1144; (b) Poulose C, Veeranarayanan S, Mohamed M S, Nagaoka Y, Aburto R R, Mitcham T, Ajayan P M, Bouchard R R, Sakamoto Y, Yoshida Y, Maekawa T and SakthiKumar D 2015 Multi-stimuli responsive $\mathrm{Cu}_{2} \mathrm{~S}$ nanocrystals as trimodal imaging and synergistic chemo-photothermal therapy agents Nanoscale 78378

28. Dutta A and Dolui S K 2008 Preparation of colloidal dispersion of $\mathrm{CuS}$ nanoparticles stabilized by SDS Mater. Chem. Phys. 112448

29. Wang Q, Li J X, Li G D, Cao X. J, Wang K J and Chen J S 2007 Formation of CuS nanotube arrays from $\mathrm{CuCl}$ Nanorods through a gas-solid reaction route J. Cryst. Growth 299386

30. Li B X, Xie Y and Xue Y 2007 Controllable synthesis of $\mathrm{CuS}$ nanostructures from self-assembled precursors with biomolecule assistance J. Phys. Chem. C 11112181

31. (a) Roy P and Srivastava S K 2007 Low-temperature synthesis of $\mathrm{CuS}$ nanorods by simple wet chemical method Mater. Lett. 61 1693; (b) Hemakanthi G, Dhathsthreyan A Ramasami T and Möbius D 2001 Preparation of copper sulphide clusters in organic-inorganic composites of Langmuir-Blodgett films of amphiphilic Schiff bases Proc. Indian Acad. Sci. (J. Chem. Sci.) 113147

32. Zhu L Y, Xie Y, Zheng X W, Liu X and Zhou G E 2004 Fabrication of novel urchin-like architecture and snowflake-like pattern CuS J. Cryst. Growth 260 494

33. Tan C H, Lu R, Xue P C, Bao C Y and Zhao Y Y 2008 Synthesis of $\mathrm{CuS}$ nanoribbons templated by hydrogel Mater. Chem. Phys. 112500

34. Zhang S, Wu C, Wu Z, Yu K, Wei J and Xie Y 2008 Construction of $\mathrm{PbSe}$ hierarchical superstructures via an alkaline etching method Cryst. Growth Des. 82933

35. (a) Ostwald W Z 1900 About the supposed isomerism of red and yellow mercuric oxide and the surface tension of solids Phys. Chem. 34 495; (b) Li B, Rong G, Xie Y, Huang L and Feng C 2006 Low-temperature synthesis of $\alpha-\mathrm{MnO}_{2}$ hollow urchins and their application in rechargeable $\mathrm{Li}^{+}$batteries Inorg. Chem. 45 6404; (c) Li J H and Zeng C 2007 Hollowing Sn-doped $\mathrm{TiO}_{2}$ nanospheres via Ostwald ripening J. Am. Chem. Soc. 129 15839

36. (a) Weimarn V P P 1925 The Precipitation Laws Chem. Rev. 2 217; (b) Nielsen A E 1960 The kinetics of calcium oxalate precipitation Acta Chem. Scand. 14 1654; (c) Johnson R A and O'Rourke J D 1954 The Kinetics of Precipitate Formation: Barium Sulfate J. Am. Chem. Soc. 76 2124; (d) Jr Day R A and Underwood A L 2013 Quantitative Analysis edn. 6 p.74; (e) Skoog D A, West D M, Holler F J and Crouch S R 2004 Fundamentals of Analytical Chemistry edn. 8 p.316

37. Gukathasan R R, Morris R H and Walker A 1983 Reactions of elemental sulphur with tetrakis (triphenylphosphine) platinum (0). Formation of a complex containing very nucleophilic bridging sulphido ligands Can. J. Chem. 612490 